\title{
PHARMACOKINETICS OF THE NEW CEREBROPETECTOR FERRUM BIS(CITRATO)GERMANATE AT THE STAGE OF ITS DISTRIBUTION TO THE ORGANS IN CLOSED HEAD INJURY
}

\author{
V.D. Lukianchuk ${ }^{1 *}$, T.A. Bukhtiarova', I.I. Seifullina², \\ E.M. Polishchuk', O.E. Martsinko ${ }^{2}$, H.A. Topolnytska ${ }^{1}$ \\ 1 - INSTITUTE OF PHARMACOLOGY AND TOXICOLOGY OF THE NATIONAL ACADEMY \\ OF MEDICAL SCIENCES OF UKRAINE, KYIV, UKRAINE \\ 2- ODESA I.I. MECHNIKOV NATIONAL UNIVERSITY, ODESA, UKRAINE
}

\begin{abstract}
Background. Previous studies showed that new coordinate compound Cerebrogerm (ferrum bis(citrato) germanate) is a promising cerebroprotector.

Objective of the study is a comparative analysis of the central stage of the pharmacokinetics of Cerebrogerm as well as its distribution in vital organs in cases of closed head injury.

Methods. On the experimental original model of closed brain injury in rats the parameters of the central stage of Cerebrogerm pharmacokinetics: the distribution in brain, liver, kidneys, were studied.

Results. It is established that, in cases of closed head injury Cerebrogerm reaches maximum concentration first in the brain (in 3.75 h), then in the kidneys (in 3.92 h), and finally in the liver (in $4.17 \mathrm{~h}$ ). In this case, the magnitude of the $C_{\max }$ of the coordinating compound of germanium that is being investigated in different biosubstrates of the rats with closed head injury may be presented in descending order as follows: brain (7.95 $\mathrm{mg} / \mathrm{L})>\operatorname{liver}(6.22 \mathrm{mg} / \mathrm{L})>$ kidneys $(1.79 \mathrm{mg} / \mathrm{L})$.

Conclusions. The compound Cerebrogerm studied easily gets through the blood-brain barrier and meets the present requirements for cerebroprotectors and antihypoxants. The attained results allow noting that in the early post-traumatic period of closed head injury, the blood circulation in the kidneys does not change and cannot modify the absorption-elimination processes of xenobiotics. It has been also established that Cerebrogerm is distributed faster in the examined organs in cases of closed head injury. The highest concentration of the drug is present in the brain and the smallest one - in the kidneys. kidneys.

KEY WORDS: ferrum bis(citrato)germanat; closed head injury; pharmacokinetics; brain; liver;
\end{abstract}

\section{Introduction}

Closed head injury is characterized by a high and steadily increasing prevalence, which is especially marked during the period of hostilities. Consequences of brain injury have significant medical and social components that are related to treatment of patients and their rehabilitation. The variety of clinical manifes_ tations and the severity of closed head injury conditioned the need to develop a strategy for scientific approaches to its pathogenetic treatment $[1,2,3]$.

In the medical practice, a very large arsenal of pharmacological methods of correction of closed head injury effects is currently used. At the same time, not all of them meet the current

${ }^{*}$ Corresponding author: Victor Lukianchuk, MD, Ph.D., DSC, Professor, Institute of Pharmacology and Toxicology of NAMS of Ukraine, 14 Anton Tsedik Str., Kyiv, 03680, Ukraine E-mail: Ivdlug@ukr.net

Phone number: $+38(044) 4569118$ *requirements for their effectiveness and safety. Therefore, the search for and development of new cerebroprotective drugs with multidimensional pharmacodynamic effects and an acceptable pharmacokinetic profile are the dilemma. In this regard, the original compounds of germanium with different bioligands based on coordination bonds are particularly interesting $[4,5,6]$.

The creation of new drugs is impossible without determination of pharmacokinetic parameters, which is a mandatory step in their preclinical studies and a prerequisite for further study of a potential drug in clinical practice. It is established that the clarification of the processes of getting drugs in the area of their pharmacodynamic effects (including cerebroprotective) has a great scientific and practical value in terms of developing a dosage regimen and optimizing rational pharmacotherapy in general. 
According to the results of screening studies on the model of traumatic brain damage in the original coordinating compounds of germanium with citric acid, it has been proved that the most active one is the complex compound ferrum bis(citrato)germanate of a conventional name Cerebrogerm [7].

The objective of the study was a comparative analysis of the central stage of the pharmacokinetics of ferrum bis(citrato)germanate, its distribution in vital organs in cases of normal as well as closed head injury.

\section{Methods}

The experiments were performed on 62 white mature inbred $160-220 \mathrm{~g}$ rats reared in the animal facility of the Institute of Pharmacology and Toxicology of the National Academy of Medical Sciences of Ukraine. All procedures were performed according to the Ukrainian legislation, the European Convention on the protection of vertebrate animals used in experimental research and for other scientific purposes (1986) and local Ethics committee. The animals were on a standard diet and received food and water ad libitum.

The experimental model of the closed head injury is an acute pathological process that developed in rats kept in a fixed modified chamber after a single application of a forcemetered and localization-oriented free-falling $45 \mathrm{~g}$-load from the height of $80 \mathrm{~cm}$ onto the parietal skull [8].

Pharmacokinetic studies were conducted in accordance with the guidelines $[9,10]$ by determining the concentrations of Cerebrogerm by germanium in pathology-free tissues of rats and in those that received the studied coordinating compound for pharmacological correction of pathological changes occurring in the early post-traumatic period in cases of closed head injury. Cerebrogerm was determined in blood serum and in vital organs: cerebral cortex, liver and kidneys by the method [11].

Sampling of biomaterials in order to determine the pharmacokinetic profile of Cerebogerm was performed in dynamics: in $0.5 ; 2 ; 6 ; 12$ and 24 hours from the time of single intraperitoneal rats injection of ferrum bis(citrato)germanate according to the previously established dosage regimen $(126 \mathrm{mg} / \mathrm{kg} 70 \mathrm{~min}$ after closed head injury) [12].

For a maximum correct evaluation of the pharmacokinetics of a potential cerebroprotector, a number of parameters was defined. These parameters characterizing the process of distribution of a potential cerebroprotector in the body of a two-chamber kinetic model with absorption in health animals and with closed head injury comprise: time of reaching the maximum concentration ( $t_{\text {max }}$, hours), maximum concentration $\left(C_{\text {max }^{\prime}} \mathrm{mg} / \mathrm{I} /\right)^{\prime}$, period of half-distribution to the organ ( $\mathrm{t}_{1 / 2, \mathrm{a}^{\prime}}$ hours), constant of the speed of direct mass transfer $\left(\mathrm{K}_{12}, \mathrm{~h}^{-1}\right)$, area under the pharmacokinetic curve (AUC, $\mathrm{mg} / \mathrm{L} \cdot \mathrm{min}$ ), period of the reverse mass transfer $\left(t_{1 / 2}\right.$, hours), constant of the speed of reverse mass transfer $\left(\mathrm{K}_{21}, \mathrm{~h}^{-1}\right)$, average time in the organ (MRT, hours).

The attained results were statistically processed on a personal computer using the Student's t-distribution criteria and Mathematica V.5.0. Differences were considered statistically significant at $p<0.05$. The statistical analysis was conducted at a $95 \%$ confidence level.

\section{Results}

The results of the pharmacokinetic study which characterize the process of distribution in organs are presented in Fig. 1 and 2 in the form of kinetic curves that indicate Cerebrogerm distribution into the brain, liver and kidneys.

Pharmacokinetic parameters that characterize the process of distribution of Cerebrogerm in vital organs of healthy animals (control group) and in those with closed head injury are presented in Table 1.

It is established that, in cases of closed head injury Cerebrogerm reaches maximum concentration first in the brain (in $3.75 \mathrm{~h}$ ), then in the kidneys (in $3.92 \mathrm{~h}$ ), and finally in the liver (in $4.17 \mathrm{~h}$ ). In this case, the magnitude of the $C_{\max }$ of the coordinating compound of germanium that is being investigated in different biosubstrates of the rats with closed head injury may be presented in descending order as follows: brain $(7.95 \mathrm{mg} / \mathrm{L})>$ liver $(6.22 \mathrm{mg} / \mathrm{L})>$ kidneys (1.79 mg/L).

At the same time, Cerebrogerm is identified in maximum concentration in the brain of healthy animals in $5.26 \mathrm{~h}$, in the kidneys in $5.10 \mathrm{~h}$ and in the liver only in $6.20 \mathrm{~h}$, with the presumable difference from the experimental group in relation to tmax in all biosubstrates. Simultaneously, under normal conditions the organs of rats can be placed according to the size of the Cmax of Cerebrogerm in descending order as follows: brain $(7.09 \mathrm{mg} / \mathrm{L})>$ liver $(5.71 \mathrm{mg} / \mathrm{L})>$ kidneys $(1.68 \mathrm{mg} / \mathrm{L})$.

The distribution (its intensity and completeness) of Cerebrogerm to the peripheral 


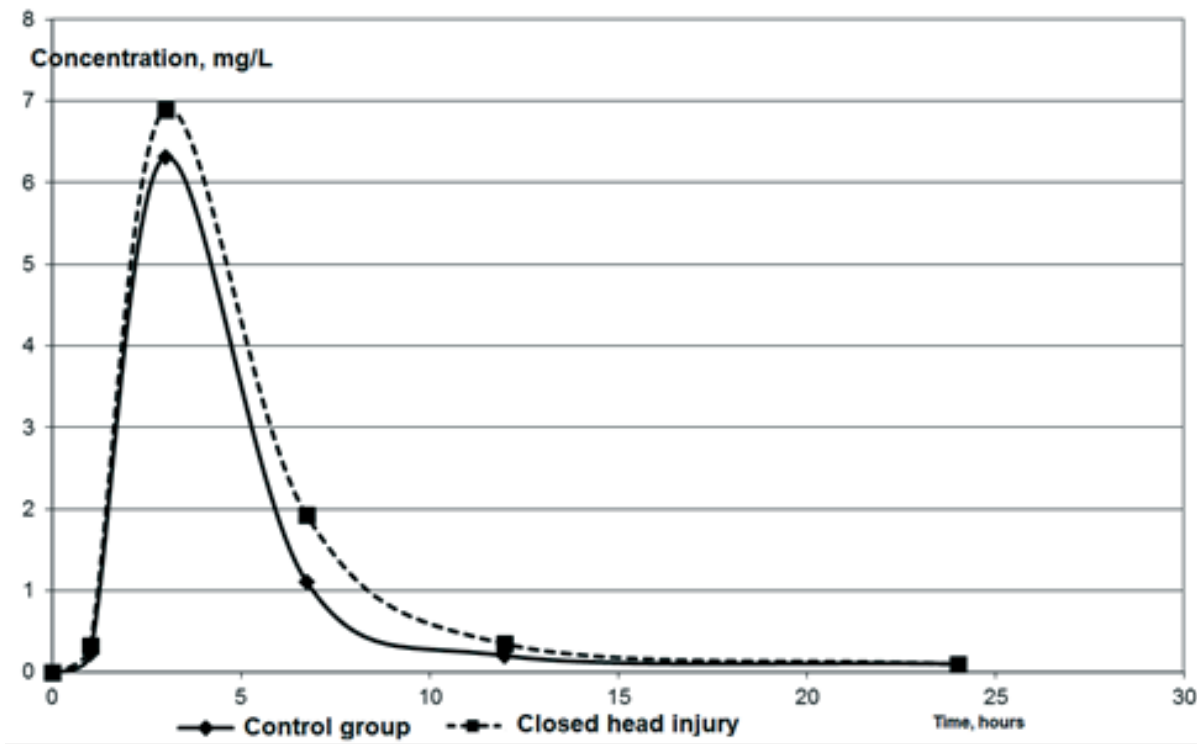

Fig. 1. Pharmacokinetic curves showing the concentration of Cerebrogerm in the brain of rats of the control group as well as in cases of closed head injury after a single intravenous injection at the dose of $126 \mathrm{mg} / \mathrm{kg}$.
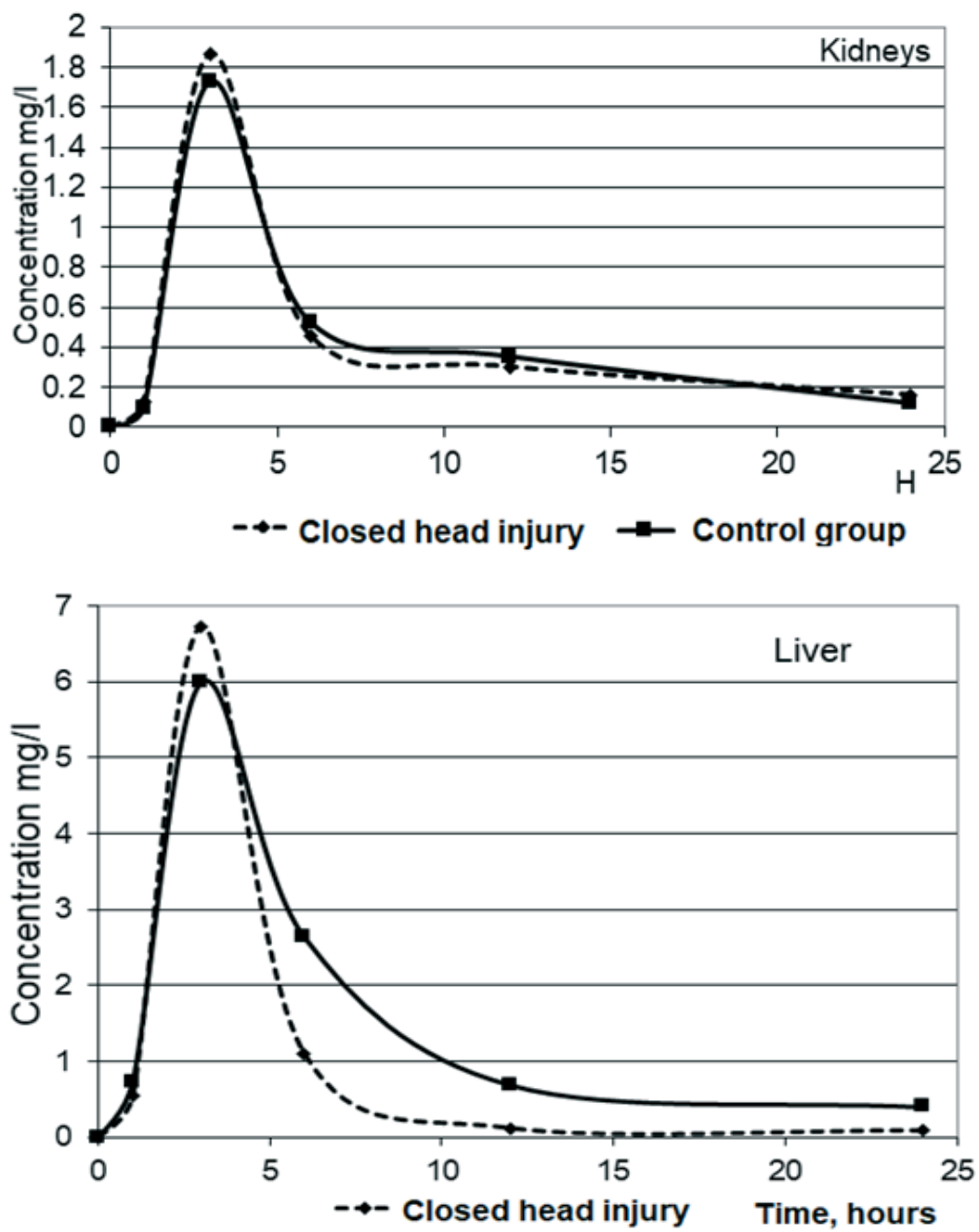

Fig. 2. Pharmacokinetic curves of the concentration of Cerebrogerm in the kidneys and liver of the control group rats as well as in those with closed head injury after a single intravenous injection at the dose of $126 \mathrm{mg} / \mathrm{kg}$. 


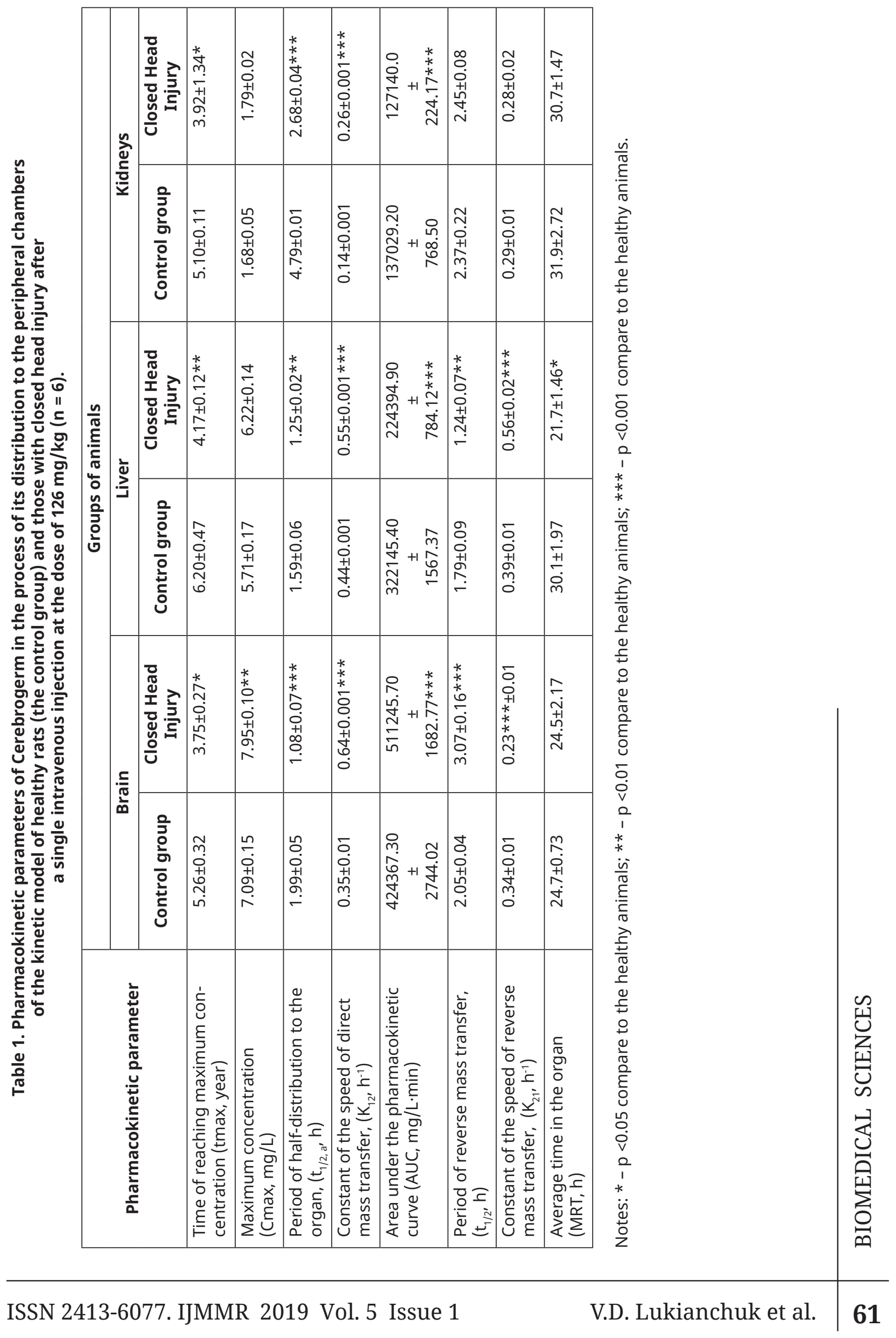


chamber is present in the half-distribution period $\left(t_{1 / 2, a,}, h\right)$ from the central chamber to the studied organs and the constant of the speed of direct mass transfer $\left(\mathrm{K}_{12}\right)$. It has been established that in cases of closed head injury (research), the coordinating compound of germanium reaches the brain the most fast, the liver slightly slower, and the kidneys the slowest, as evidenced by the parameters of $\mathrm{t}_{1 / 2, a^{\prime}}$ which denotes the time of reaching the levels of the compound which is equal to $50 \%$ of equilibrium concentrations between blood and other tissues.

Taking into account that the parameter $\mathrm{K}_{12}$ defines the relation $\mathrm{K}_{12}=0.693 / \mathrm{t}_{1 / 2^{\prime} \mathrm{a}^{\prime}}$ that is the parameter is inversely proportional to the halfdistribution period in the organs, then the revealed changes of $\mathrm{K}_{12}$ also confirm the abovedescribed character of the distribution of the compound in the organs. It is established that Cerebrogerm in both groups of animals equally enters the kidneys slowly, and the brain - the most intensively.

Such a parameter as the area under the pharmacokinetic curve (AUC) is particularly informative. It is proportional to the amount of the compound present in blood. It was established that under normal conditions the highest concentration of the drug was revealed in the brain and the smallest - in the kidneys. The following sequence follows the AUC indices: brain > liver > kidneys (see Table 1).

A comparative estimation of the AUC of pathology-free animals and those of the experimental group indicates a significant difference between the concentrations of Cerebrogerm in liver. It is established that the potential cerebroprotector is revealed in the liver under normal conditions by $43.6 \%$ more than in cases of closed head injury.

It should be noted that Cerebrogerm enters the brain $\left(t_{1 / 2, a}\right)$ very fast, but eliminates $\left(t_{1 / 2}\right)$ slowly in both compared groups of animals. It is significant that Cerebrogerm is almost identically eliminated from the kidneys of the rats with or without traumatic brain damage ( $p>0.05)$.

Similarly, the organs are classified according to the constant of the speed of reverse mass transfer. As presented in Table 1, Cerebrogerm eliminates from the liver of the animals of the experimental group the fastest and from the brain the slowest.

Among the pharmacokinetic parameters studied during the preclinical stage, the average time the compound stays in the body has high informational value since the implementation of the pharmacological effect of a drug directly depends on its time in the whole body as well as in a particular organ or tissue. The results presented in Table 1 evidence that in the pathology-free animals the studied organs are classified according to the MRT decrease as follows: kidneys (31.9 h)> liver (30.1 h)> brain (24.7 h).

In cases of traumatic brain damage, Cerebrogerm is eliminated by $27.9 \%$ faster ( 21.7 hours) from the liver with no significant differences in MRT of the brain and kidneys ( $p<0.05)$.

\section{Discussion}

The attained data, which characterizes the speed of Cerebrogerm being delivered from blood to various animal organs (see Table 1), indicates that coordination compound of germanium enters the peripheral chambers of the biokinetic model in different speed and amount both under normal and closed head injury conditions. It is worth noting that Cerebrogerm passes through the histo-hematic barriers of the studied organs in different speed.

The defined pharmacokinetic parameters of Cerebrogerm, characterizing the process of getting from the peripheral chambers of the kinetic model into the blood under normal conditions as well as in cases of closed head injury, require more detailed analysis and discussion. Particular attention should be paid to the period of reverse mass transfer $\left(\mathrm{t}_{1 / 2}\right)$, that is the time the compound returns to the central circulation of the peripheral chamber (organ). According to this indicator, the pathology-free organs of the animals take the order of: liver $>$ kidneys $>$ brain.

The revealed character of the distribution of Cerebrogerm in cases of closed head injury indicates, in our opinion, the direction of its action in terms of cerebroprotective effect. Under normal conditions in the animals Cerebrogerm is first rewealed in liver, and then in the brain and kidneys.

In this case, a $32.4 \%(P<0.001)$ decrease was defined in the rate of the reverse mass transfer constant of Cerebrogerm from the brain into the blood in cases of closed head injury caused by post-traumatic exudation of the brain tissue which was subjected to mechanical damage.

Consequently, cerebral edema which occurs in cases of closed head injury makes the coordination of germanium stay in the brain longer that eventually causes a decrease in the 
speed of Cerebrogerm transition from the brain into the bloodstream.

This data reaffirms our hypothesis about cerebral edema, which impedes the transition of Cerebrogerm from the brain into the blood, as evidenced by $(p<0.001)$ increase of the AUC indices by $20.5 \%$ in cases of closed head injury compare to normal conditions.

This experimentally proved fact can indirectly show the detoxification function of the liver being saved in terms of its direct involvement in the processes of elimination of Cerebrogerm as a xenobiotic.

Thus, it should be noted that in the early post-traumatic period of closed head injury, blood circulation in kidneys does not change to the extent that might substantially modify the absorption-elimination processes of xenobiotics. This is quite appropriate in view of the fact that kidneys have rich blood supply.

Thus, the results of the complex preclinical studies prove that the defined pharmacokinetic profile of the distribution of Cerebrogerm in cases of closed mechanical brain trauma differs from that under the normal conditions. It has been experimentally proved that Cerebrogerm enters the examined organs in cases of closed head injury faster than it does without it. It should be noted that the highest concentration of the drug, as evidenced by the area under the pharmacokinetic curve, occurs in the brain of the animals with closed head injury and the smallest - in the kidneys.

This should be considered as a key pharmacokinetic parameter that clearly proves the ability of Cerebrogerm to get through the blood-brain barrier. The attained data also proves that the coordination compound of germanium corresponds precisely to the current requirements for cerebroprotectors and antihypoxants. This kind of drugs is capable to implement a number of pharmacodynamic effects through the accumulation in the brain, as in the central biophase. These effects aim at organ protection, mainly the protection of cerebral neurons.

\section{Conclusions}

Determination of the pharmacokinetic parameters of the potential cerebroprotector ferrum bis(citrato)germanate at the stage of its distribution in the body in cases of traumatic brain damage indicates a significant modification of the kinetic profile of the compound compared to the normal conditions. A number of parameters that characterize the process of Cerebrogerm's distribution from the central chamber to the peripheral $\left(\mathrm{t}_{1 / 2, \mathrm{a}^{\prime}} \mathrm{K}_{12^{\prime}} \mathrm{K}_{21}\right.$, AUC) substantially $(P<0.05-0.001)$ undergoes a 'traumatic' correction. According to the parameters characterizing the pharmacokinetic spectrum of the distribution of Cerebrogerm into organs, it can be represented in the following order: brain > liver > kidneys.

The studied compound Cerebrogerm easily gets through the blood-brain barrier and meets the present requirements for cerebroprotectors and antihypoxants. The attained results allow noting that in the early post-traumatic period of closed head injury, the blood circulation in the kidneys does not change and cannot modify the absorption-elimination processes of xenobiotics. It has been also established that Cerebrogerm is distributed faster in the examined organs in cases of closed head injury. The highest concentration of the drug is present in the brain and the smallest one - in the kidneys.

\section{Conflict of interest}

The authors declare no conflict of interest.

\title{
ФАРМАКОКІНЕТИКА НОВОГО ЦЕРЕБРОПРОТЕКТОРА ФЕРУМ БІС(ЦИТРАТО) ГЕРМАНАТУ НА ЕТАПІ ЙОГО РОЗПОДІЛУ В ОРГАНИ НА ТЛІ ЗАКРИТОЇ ЧЕРЕПНО-МОЗКОВОЇ ТРАВМИ
}

\author{
В.Д. Лук'янчук'1, Т.А. Бухтіарова', І.Й. Сейфулліна², \\ Є.М. Поліщук', О.Е. Марцинко2, Г.А. Топольницька ${ }^{1}$ \\ 1 - ДУ "ІНСТИТУТ ФАРМАКОЛОГЇ̈ ТА ТОКСИКОЛОГІЇ НАМН УКРАЇНИ", КИЇВ, УКРАЇНА \\ 2 - ОДЕСЬКИЙ НАЦІОНАЛЬНИЙ УНІВЕРСИТЕТ ІМЕНI I.I. МЕЧНИКОВА, ОДЕСА, УКРАÏНА
}

Вступ. Попередні скринінгові фармако- та токсикометричні дослідження нової координаційної сполуки Цереброгерм (ферум біс(цитрато)германат) показали, що це перспективний потенційний засіб церебропротекції. 
Мета дослідження - провести порівняльний аналіз центрального етапу фармакокінетики Цереброгерму - розподілу у життєвоважливі органи: головний мозок, печінка, нирки, в нормі та при ЗчMT.

Матеріали. На оригінальній моделі зчМт визначали низку фармакокінетичних параметрів ферум біс(цитрато)германату що всебічно характеризують процес розподілу в периферичні камери моделі в нормі та за умов ЗЧМТ.

Результати. Показано, що при зчМТ максимум концентрації Цереброгерму досягається спочатку у мозку (після 3,75 год), потім у нирках (після 3,92 год) та у печінці (після 4,17 год). В той же час, за величиною $C_{\text {max }}$ Цереброгерму органи щурів контрольної групи можна розташувати у порядку зменшення наступним чином: головний мозок (7,09 мг/л) > печінка $\left(5,71\right.$ мг/л)> нирки $\left(1,68\right.$ мг/л). Величина $C_{\max }$ координаційної сполуки германію у щурів із зЧМТ виглядає так: головний мозок (7,95 мг/л) > печінка (6,22 мг/л)> нирки (1,79 мг/л).

Висновки. Отримані дані дозволяють дійти висновку, що досліджувана сполука доволі легко проникає через гематоенчефалічний бар'єр і відповідає сучасним вимогам до черебропротекторів та антигіпоксантів. Отримані результати дозволяють зазначити, що у ранньому постравматичному періоді зчмТ стан кровообігу у нирках не змінюється у такій мірі, щоби суттєво модифікувати абсорбційно-елімінаційні прочеси ксенобіотика. Доведено також, що за умов зЧмТ Цереброгерм надходить до органів, що досліджувались, більш швидко, ніжу здорових шурів. Найбільща концентрація препарату, про яку судили за показником площі під фармакокінетичною кривою, знаходиться у головному мозку, а найменша - в нирках травмованих тварин.

КЛЮчОВI СЛОВА: ферум біс(цитрато)германат; закрита черепно-мозкова травма; фармакокінетика; головний мозок; печінка; нирки.

\section{Інформація про авторів}

Лук'янчук Віктор Дмитрович - д-р мед. наук, професор, головний науковий співробітник Відділу медичної хімії, ДУ “Інститут фармакології та токсикології НАМН України”, м. Київ, Україна.

Бухтіарова Тетяна Анатоліївна - член-кореспондент НАМН України, д-р мед. наук, директор ДУ "Інститут фармакології та токсикології НАМН України", м. Київ, Україна.

Сейфулліна Інна Йосипівна - д-р хімічних наук, професор, завідувач кафедрою загальної хімії та полімерів Одеського національного університету імені I.I. Мечнікова, м. Одеса, Україна.

Поліщук Євген Миколайович - канд. мед. наук, пошукувач ДУ “Інститут фармакології та токсикології НАМН України", м. Київ, Україна.

Марцинко Олена Едуардівна - д-р хімічних наук, професор кафедри загальної хімії та полімерів Одеського національного університету імені I.I. Мечнікова, м. Одеса, Україна.

Топольницька Ганна Андріївна - пошукувач ДУ “Інститут фармакології та токсикології НАМН України", м. Київ, Україна.

\section{Information about authors}

Victor Lukianchuk - MD, Ph.D., DSc, Professor, Institute of Pharmacology and Toxicology of NAMS of Ukraine, Kyiv, 03680, Ukraine.

ORCID 0000-0002-7734-4739, e-mail: Ivdlug@ukr.net

Tetiana A. Bukhtiarova - MD, Ph.D., DSc, corresponding member of NAMS of Ukraine, Institute of Pharmacology and Toxicology of NAMS of Ukraine, Kyiv, 03680, Ukraine.

e-mail: bukhtiarova@yahoo.com

Inna I. Seifullina - Ph.D., DSc, professor, Head of the Department of General Chemistry and Polymers, Odesa I.I. Mechnikov National University, Odesa, Ukraine.

Evgen M. Polishchuk - MD, Ph.D., Institute of Pharmacology and Toxicology of NAMS of Ukraine, Kyiv, 03680, Ukraine.

e-mail: polishchyk@ukr.net

Olena E. Martsinko - Ph.D., DSc, professor, Department of General Chemistry and Polymers, Odesa I.I. Mechnikov National University, Odesa, Ukraine.

e-mail: Iborn@ukr.net

Hanna A. Topolnytska - Institute of Pharmacology and Toxicology of NAMS of Ukraine, Kyiv, 03680, Ukraine. 


\section{References}

1. Shevchuk OV. Experimental ground for a-lipoic acid use in closed head injury. [AutoAbstract]. Kyiv: Institute of Pharmacology and Toxicology of NAMS of Ukraine; 2007. 21 p. [In Ukrainian]

2. Sadovnik OV. The efficacy of Corvitin in closed head injury. [AutoAbstract]. Kharkiv: National Pharmaceutical University; 2011. 20 p. [In Ukrainian]

3. Fedorova VS. The efficacy of acetylcysteine in closed head injury. [AutoAbstract]. Kharkiv: National Pharmaceutical University; 2012. 18 p. [In Ukrainian]

4. Vysotska LV. The search of cerebroprotectors among the new compounds of germanium with bioligands. [AutoAbstract]. Kharkiv: National Pharmaceutical University; 2009. 20 p. [In Ukrainian]

5. Rysukhina NV. The search of means to correct endotoxicities of posttraumatic origin [AutoAbstract]. Kyiv: Institute of Pharmacology and Toxicology of NAMS of Ukraine; 2010. 20 p. [In Ukrainian]

6. Lukianchuk VD, Nizhenkovsky OI, Fedorova VS, Kravets DS, Seifullina II, Martsinko OE, Pesaroglo OG. Screening analysis of coordination compounds of germanium in model of closed head injury. Pharmacology and Drug Toxicology. 2012;6:63-8 [In Ukrainian].

7. Lukianchuk VD, Polishchuk EM, Seifullina II, Rysukhina NV, Martsinko OE, Chebanenko OA.
Comparative estimation of cerebroprotective activity of newly synthesized coordination compounds of germanium in the model of closed head injury. Pharmacology and Drug Toxicology. 2014;38(2):36-43 [In Ukrainian].

8. Lukianchuk VD, Shevchuk OV, Badinov OV, assignee. The animal model of closed head injury; Luhansk State Medical University. Ukraine patent UA 13678. 2006 April 17. 8 p. [In Ukrainian]

9. Kravets DS. Optimization of calculation of parameters of chemobiokinetics using the EOM software. Ukrainian Medical Almanakh. 2000; 2:90-1 [In Russian].

10. Golovenko NYa, Lukianchuk VD, Zhuk OV, Zinkovsky VG, Kravets DS, Zhuk MS. Methodical recommendations in computer calculation of pharmacokinetics parameters of drugs. Kyiv: State Scientific-Expertise Center; 1999. 70 p.

11. Kresiun VI, Vidavska AG, Shemonaeva KF. Extraction-fotometric evaluation of micro amounts of germanium in tissues of experimental animals. Odesa Medical Journal. 2000;62(6):7-11.

12. Polishchuk EN, Kravets DS. Experimental mathematical analysis of dose regimen of potential cerebroprotector Cerebrogerm. Medical Journal of Western Kazakhstan. 2014; 44(4): 26-31 [In Russian].

Received 22 February 2019; revised 22 March 2019; accepted 25 April 2019.

This is an open access article distributed under the Creative Commons Attribution License, which permits unrestricted use, distribution, and reproduction in any medium, provided the original work is properly cited. 